\title{
Factors Affecting the Need for Feasibility Analysis (For Local Construction Projects)
}

\author{
Muneer Anees ${ }^{1}$, Syed Mustafa Hussain ${ }^{2}$, Kamran Khan ${ }^{3}$, Agha Taqi Abbas ${ }^{4}$
}

\begin{abstract}
In Pakistan, the majority of the local construction projects are opted without feasibility analysis on the basis of previously worked data without examining the current scenario. However, for foreign-funded project feasibility analysis along with standard guidelines is conducted, but in case of domestically funded projects, it is often omitted. This research has uncovered critical factors affecting feasibility for the local construction industry of Pakistan. Field data are extracted from ongoing construction projects which are domestically funded. Relative Importance Index (RII) analysis was carried out first to rank the factors in terms of their perceived importance. Spearman's rank correlation analysis was also done in this regard. The findings of the study might promote construction practitioners to focus on the need for feasibility analysis for local projects too.
\end{abstract}

Index Terms - Feasibility analysis, Stakeholders, Relative Importance Index, Spearman's rank correlation.

\section{INTRODUCTION}

Feasibility analysis is a detailed study of how successful a project can be completed, accounting for factors that affect it such as economic, technological, legal and scheduling factors [1]. Feasibility analysis is used by project inceptors, to determine potential positive and negative outcomes of a project before investing a considerable amount of time and money into it. Feasibility analysis allows to, determine and organize all of the necessary details to make a business work. It is helpful to identify logistical problems, and nearly all business-related problems, along with the solutions to alleviate them. Feasibility studies are normally conducted to justify investments in infrastructure projects [2]. Despite the vital importance of feasibility studies in supporting decisions related to public spending on projects, there are no attempts to evaluate such studies after construction of facilities. This paper defines those factors that affect and influences need of feasibility analysis for local construction projects. Opinion from stakeholders will be extracted in order to determine the most crucial factors. Furthermore, the level of agreement among all stakeholders will be determined upon the subject so as to have a better understanding of perception about the feasibility analysis in the construction industry.
The objective of this research work is to identify the crucial factors that lead towards the feasibility analysis for local projects. The aim is also to study the influence of the identified factors on feasibility analysis. The feasibility study of a project is an approximation of the possible profits of that project or a study that measures the probable benefits of a certain project relative to its cost. Owners, decision makers, and financial institutions build their decisions to proceed with and/or finance any project based on the results of the feasibility study of that project [3].

\section{RESEARCH METHODOLOGY}

\section{A. Method of Analysis}

The main purpose of this research is to identify major affecting factors for need for feasibility analysis for local projects in the construction industry of Pakistan and to evaluate whether there is an agreement or disagreement among the opinions of each pair of major stakeholder/ respondent groups, i.e., client, consultant and contractor. In the first stage, secondary data has been gathered from various sources through qualitative data collection techniques. The data adopted, has been utilized for the development of a questionnaire.

In the second stage, primary data has been gathered from questionnaire survey, through quantitative data collection technique. An opinion of all three principal stakeholders of the construction industry (i.e., client, consultant and contractor), has been gathered in this regard, to obtain a wider perspective. The gathered information was finally used to explore the perception of Pakistani construction industry, regarding the feasibility analysis. The designed questionnaire will be distributed to three principal stakeholders (client, consultant and contractor) of the construction industry of Pakistan. Each respondent was requested to rank 25 identified factors influencing feasibility analysis, in the construction industry of Pakistan [4].

The details of important factors affecting the need of feasibility with respect to different countries are defined in Table I:

\footnotetext{
${ }^{1}$ Junior Lecturer, Department of Civil Engineering, Sir Syed University of Engineering \& Technology, Karachi, Pakistan.. manees@ ssuet.edu.pk

${ }^{2}$ Graduate Student, Department of Civil Engineering, NED University of Engineering \& Technology, Karachi, Pakistan.. syedmustafahussain027@ gmail.com

${ }^{3}$ Assistant Professor, Department of Civil Engineering, Sir Syed University of Engineering \& Technology, Karachi, Pakistan. kkhan@ ssuet.edu.pk

${ }^{4}$ Managing Partner, A3M Construction Co., Karachi, Pakistan. agha.taqi@a3mengg.com
} 
Table I: Important Factor affecting the Need of Feasibility, according to Different Countries

\begin{tabular}{|c|c|c|c|c|}
\hline $\begin{array}{c}\text { Coun } \\
\text { try }\end{array}$ & Researcher & Year & $\begin{array}{c}\text { Fact } \\
\text { ors }\end{array}$ & $\begin{array}{l}\text { Important Factors Affecting } \\
\text { Need Of Feasibility Analysis }\end{array}$ \\
\hline $\begin{array}{l}\text { Malay } \\
\text { sia }\end{array}$ & $\begin{array}{l}\text { C.S.J.JP; } \\
\text { A.H.J., and } \\
\text { Rawshan Ara } \\
\text { Begum [3] }\end{array}$ & 2006 & 2 & $\begin{array}{l}\text { Environmental Assessment, } \\
\text { Quality of work }\end{array}$ \\
\hline Egypt & $\begin{array}{l}\text { Azza Abou- } \\
\text { Zeid Ashraf } \\
\text { Bushraa and } \\
\text { Maged } \\
\text { Ezzat[4] }\end{array}$ & 2007 & 5 & $\begin{array}{l}\text { Contractual Agreements, } \\
\text { Government policies, maintenance } \\
\text { and revamping, life of the project, } \\
\text { resettlement management. }\end{array}$ \\
\hline $\begin{array}{l}\text { Canad } \\
\text { a }\end{array}$ & LC Goode [5] & 1991 & 5 & $\begin{array}{l}\text { Viability of the project, cash } \\
\text { flows, socioeconomic impacts, } \\
\text { psychological impacts, financial } \\
\text { turnover }\end{array}$ \\
\hline $\begin{array}{l}\text { Jorda } \\
\mathrm{n}\end{array}$ & $\begin{array}{l}\text { A.K Khaleid } \\
\text { Hyari [6] }\end{array}$ & 2009 & 6 & $\begin{array}{l}\text { Budgeting, opting projects beyond } \\
\text { limits, financial turnovers, value } \\
\text { engineering, Law and order } \\
\text { situation. Logistics management. }\end{array}$ \\
\hline USA & $\begin{array}{l}\text { Jason B. } \\
\text { Forsyth [7] }\end{array}$ & 2011 & 1 & Utilization of a scarce resource. \\
\hline China & $\begin{array}{l}\text { L.V.S. Rotterc } \\
{[8]}\end{array}$ & 2010 & 4 & $\begin{array}{l}\text { Supply of material from distant } \\
\text { areas, workability of the Project, } \\
\text { hurdles identification. Marketing } \\
\text { strategy. }\end{array}$ \\
\hline USA & $\begin{array}{l}\text { M.F. Bonsang } \\
\text { Koo [9] }\end{array}$ & 2011 & 1 & Time delays \\
\hline USA & $\begin{array}{l}\text { Shabtai Isaac } \\
{[10]}\end{array}$ & 2008 & 2 & $\begin{array}{l}\text { New technology, resource } \\
\text { management }\end{array}$ \\
\hline
\end{tabular}

\section{B. Method of Analysis and Results}

In order to facilitate the analysis process, the respondents were asked to rank 25 identified factors on the scale of 1 to 4 . Following numerical values are assigned to the respondents' rating: 1 = Extremely Unimportant, 2 = Unimportant, $3=$ Important, 4 = Extremely Important.

The respondent response (on the scale of 1 to 4) was then being converted into a Relative Importance Index (RII), using the following formula:

$$
R I I=\frac{\sum W}{(H)(N)}
$$

Where:

$\mathrm{W}=$ Total weight, given to each factor by the respondents, which ranges from 1 to 4 and is calculated by an addition of the various weightings given to a factor by all respondents.

$\mathrm{H}=$ Highest ranking available (i.e. 4 in this case),

$\mathrm{N}=$ Total number of responses.

To determine the degree of agreement or disagreement among the ranking of each pair of a respondent group (i.e., client, consultant \& contractor) statistically, a statistical test will be conducted using the Spearman's rank correlation coefficient. The Spearman's rank correlation coefficient is used to test the agreement or disagreement between the two rankings. The Spearman's correlation coefficient ranges from -1 to +1 , where -1 represent disagreement (perfect negative correlation) and +1 represent an agreement (perfect positive correlation). The Spearman's rank correlation coefficient (RS) is represented by the following equation:

$R S=1-\frac{6 \sum d^{2}}{N\left(N^{2}-1\right)}$
Where:

$\mathrm{d}=$ Difference between the Rankings.

$\mathrm{N}=$ Number of Implementation Plans.

\section{RESULTS}

Overall analysis based on 56 responses out of 100 responses which were received from construction professionals involved in the construction industry of Pakistan. While extensive experience (i.e., greater than 5 years) is the selection criteria of these 56 responses among other responses for analysis purpose. Out of these 56 responses, 14 responses received from client, 19 responses received from consultants and 23 responses received from contractors. The percentage of the responses received according to the, respondent type is represented in Fig. 1.

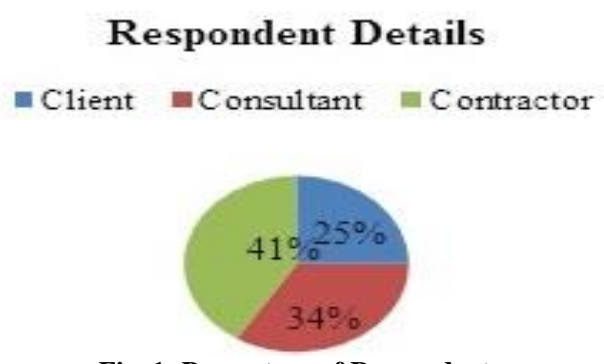

Fig. 1: Percentage of Respondents

The following discussion is based on the result of the survey which provides valuable information about the critical factors affecting feasibility analysis for any construction project. Table II shows the relative importance index of Twenty-five (25) identified factors and their rankings. These factors were rated by three different stakeholders, i.e. client, consultant \& contractor. From Fig. 2 it is evident that the eight most important factors, as perceived by stakeholders (clients, consultants and contractors).

Spearman's coefficient of rank correlation is used to disclose whether there is agreement or disagreement between each pair of respondents. Table II illustrates the results of Spearman's coefficient calculations. A conclusion can be drawn from these results that there is an attractive correlation between contractors and consultants because contractors suffer the most, usually in terms of delays, cost overruns etc., if the project is not feasible. The resources and capital of contractor are exposed to risk always. Therefore, he seeks much interest in conducting a feasibility analysis of the project. However, it is also observed that there is least agreement between clients and consultants [5]. Client although is a funding agency, but except finance, none of its resources are at stake. Often clients, in local projects do not give importance to feasibility studies, due to which project suffers losses in many ways. Consultants emphasize due to its importance but their perception is very much different from that of clients. Consultant focuses on technicalities and mitigating design hurdles whereas Client focuses on finance majorly, than on technical aspects of any project. The agreement between client and contractor is quite much justified as both stakeholders have fewer factors in common [6]. 
Table II: Factors Identified for the Need of the Feasibility Study

\begin{tabular}{|c|c|c|c|c|c|c|c|c|c|}
\hline \multirow{2}{*}{ S\# } & \multirow{2}{*}{ Description } & \multicolumn{2}{|c|}{ Client } & \multicolumn{2}{|c|}{ Consultant } & \multicolumn{2}{|c|}{ Contractor } & \multicolumn{2}{|c|}{ OVERALL } \\
\hline & & RII & Rank & RII & Rank & RII & Rank & RII & Rank \\
\hline 1 & $\begin{array}{l}\text { For incorporation of modern technology in } \\
\text { construction project. }\end{array}$ & 0.75 & 4 & 0.88 & 2 & 0.84 & 4 & 0.82 & 4 \\
\hline 2 & For value engineering of the project. & 0.75 & 4 & 0.88 & 2 & 0.86 & 2 & 0.83 & 3 \\
\hline 3 & To cater foreseen time delays. & 0.68 & 17 & 0.80 & 14 & 0.77 & 14 & 0.75 & 17 \\
\hline 4 & $\begin{array}{l}\text { For making an efficient budget and cash flow } \\
\text { to avoid cost overruns. }\end{array}$ & 0.75 & 4 & 0.91 & 1 & 0.85 & 3 & 0.84 & 2 \\
\hline 5 & $\begin{array}{l}\text { For making an efficient budget and cash flow } \\
\text { to avoid cost overruns. }\end{array}$ & 0.70 & 12 & 0.72 & 23 & 0.72 & 24 & 0.71 & 24 \\
\hline 6 & $\begin{array}{l}\text { For identifying the organization that opts } \\
\text { project beyond their financial and technical } \\
\text { limits. }\end{array}$ & 0.70 & 12 & 0.72 & 23 & 0.67 & 25 & 0.70 & 25 \\
\hline 7 & $\begin{array}{l}\text { For understanding viability and need of a } \\
\text { project. }\end{array}$ & 0.91 & 1 & 0.86 & 5 & 0.90 & 1 & 0.89 & 1 \\
\hline 8 & $\begin{array}{l}\text { Psychological impacts upon the lives of } \\
\text { nearby people that are affected by the project. }\end{array}$ & 0.68 & 17 & 0.78 & 18 & 0.75 & 21 & 0.74 & 21 \\
\hline 9 & $\begin{array}{l}\text { Socioeconomic impact upon the business of } \\
\text { the nearby people. }\end{array}$ & 0.73 & 9 & 0.75 & 22 & 0.77 & 14 & 0.75 & 17 \\
\hline 10 & For environmental assessments & 0.68 & 17 & 0.84 & 8 & 0.79 & 10 & 0.77 & 10 \\
\hline 11 & $\begin{array}{l}\text { For developing a sound financial turnover } \\
\text { mechanism. }\end{array}$ & 0.70 & 12 & 0.86 & 5 & 0.79 & 10 & 0.78 & 8 \\
\hline 12 & $\begin{array}{l}\text { For incorporating taxation and government } \\
\text { monetary policies. }\end{array}$ & 0.63 & 23 & 0.83 & 11 & 0.78 & 12 & 0.75 & 19 \\
\hline 13 & $\begin{array}{l}\text { To foresee the fluctuations in law and order } \\
\text { of the country. }\end{array}$ & 0.59 & 25 & 0.84 & 8 & 0.77 & 14 & 0.73 & 22 \\
\hline 14 & $\begin{array}{l}\text { For considering level of resettlement } \\
\text { management. }\end{array}$ & 0.63 & 23 & 0.76 & 21 & 0.76 & 18 & 0.72 & 23 \\
\hline 15 & $\begin{array}{l}\text { For determining the allocation of scarce } \\
\text { resources (example: Water Scarce areas). }\end{array}$ & 0.66 & 22 & 0.80 & 14 & 0.84 & 4 & 0.77 & 11 \\
\hline 16 & $\begin{array}{l}\text { To identify hurdles at work due to } \\
\text { encountering of utilities } \\
\text { premises. }\end{array}$ & 0.70 & 12 & 0.82 & 13 & 0.78 & 12 & 0.77 & 11 \\
\hline 17 & $\begin{array}{l}\text { For logistics management during the } \\
\text { execution phase. }\end{array}$ & 0.75 & 4 & 0.84 & 8 & 0.74 & 22 & 0.78 & 9 \\
\hline 18 & $\begin{array}{l}\text { To examine the supply of required material } \\
\text { along with 20prioritizing whether to use local } \\
\text { made (nearby areas) or imported (distant } \\
\text { areas). }\end{array}$ & 0.77 & 3 & 0.70 & 25 & 0.83 & 6 & 0.77 & 11 \\
\hline 19 & For making a quality management system. & 0.68 & 17 & 0.86 & 5 & 0.83 & 6 & 0.79 & 7 \\
\hline 20 & $\begin{array}{l}\text { For generating a procurement cycle to } \\
\text { arrange resources timely. }\end{array}$ & 0.70 & 12 & 0.88 & 2 & 0.80 & 9 & 0.79 & 6 \\
\hline 21 & $\begin{array}{l}\text { For developing an effective marketing } \\
\text { strategy. }\end{array}$ & 0.68 & 17 & 0.79 & 16 & 0.76 & 18 & 0.74 & 20 \\
\hline 22 & $\begin{array}{l}\text { To define the life of a project along with its } \\
\text { workability. }\end{array}$ & 0.71 & 11 & 0.79 & 16 & 0.77 & 14 & 0.76 & 14 \\
\hline 23 & $\begin{array}{l}\text { To determine the specific period when } \\
\text { revamping and modernization of the project } \\
\text { is needed according to new trends \& } \\
\text { technology. }\end{array}$ & 0.73 & 9 & 0.78 & 18 & 0.76 & 18 & 0.76 & 14 \\
\hline 24 & $\begin{array}{l}\text { For computing total life and salvage value of } \\
\text { the project. }\end{array}$ & 0.75 & 4 & 0.78 & 18 & 0.74 & 22 & 0.76 & 14 \\
\hline 25 & $\begin{array}{l}\text { For determination of type of contractual } \\
\text { agreement to be used. Example: BOT, DBO } \\
\text { etc. }\end{array}$ & 0.80 & 2 & 0.83 & 11 & 0.83 & 6 & 0.82 & 5 \\
\hline
\end{tabular}




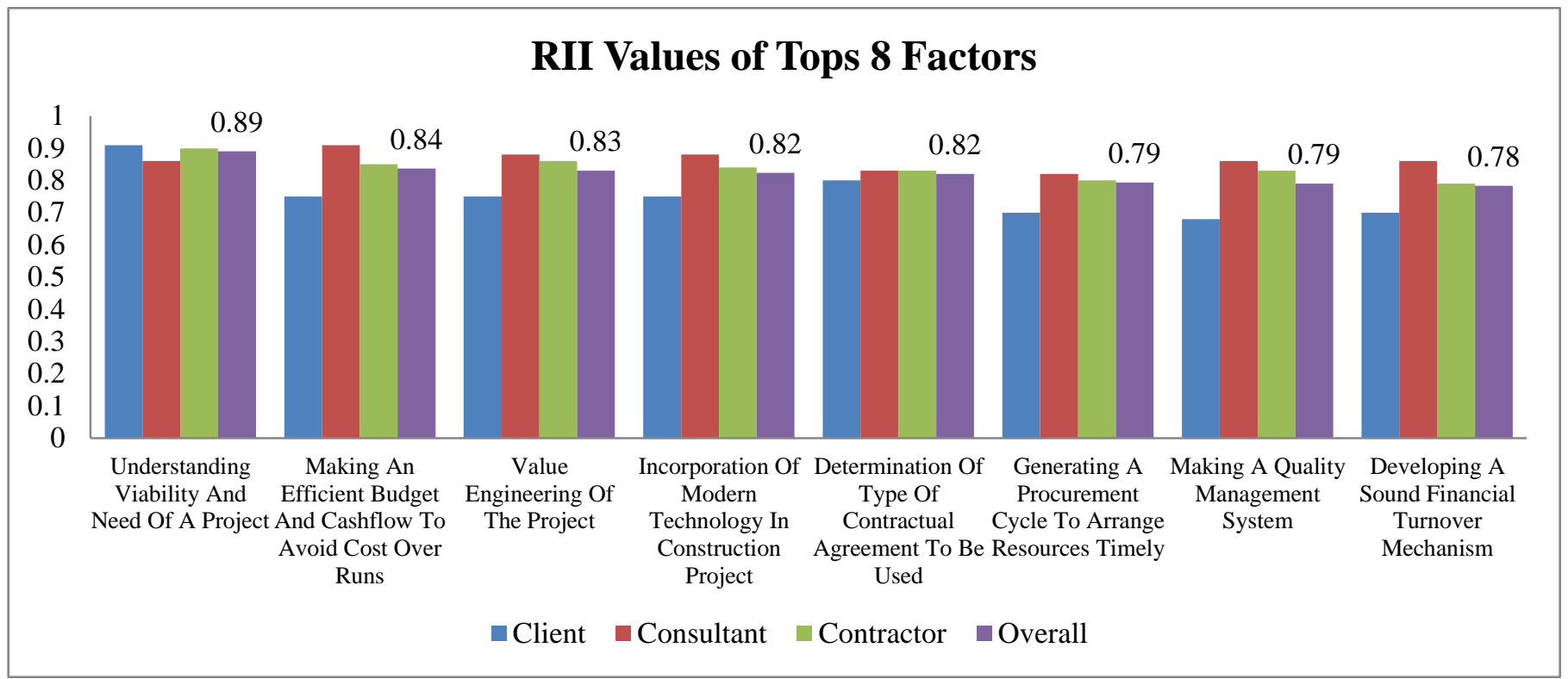

Fig. 2: RII Ranking of Top 8 Factors

Table III: Spearman's Rank Correlation Results

\begin{tabular}{|l|c|}
\hline \multicolumn{1}{|c|}{ Respondents Pair } & $\begin{array}{c}\text { Spearman's Rank } \\
\text { Correlation Coefficient }\end{array}$ \\
\hline Contractors - Consultants & $64 \%$ \\
\hline Consultants - Clients & $15 \%$ \\
\hline Contractors - Clients & $27 \%$ \\
\hline
\end{tabular}

\section{DISCUSSION}

The most crucial factors, according to the conducted survey, are:

\section{A. Modern Technology}

In this modern era of mechanization and efficient technology, it is very much necessary to indulge latest and updated equipment and techniques in a project. This not only is going to save much amount of a time, but will also be fruitful in obtaining optimum results. To gain maximum returns within stipulated time, the incorporation of modern technology is vital. This plan is moderately rated by the respondents [7].

\section{B. Value Engineering}

The value of any project can be enhanced either by improving the functionality or by reducing the cost. It is a primary perspective of value engineering that basic functions are preserved rather than reduce pursuing the value improvements. For any project, it is necessary to examine the value of returns as well as of cost. It is highly ranked by our respondents [8].

\section{Cash Flow}

In the Construction industry of Pakistan, cost overruns have been the most common and dominant factor that led towards backlog in this sector. Budget allocation and financial management have always been an issue that affects the progress of the project as well as the returns expected from it.
Hence an effective cash flow must be formulated to minimize cost overruns. This is second most highly rated by the respondents [9].

\section{Viability}

This is the most highly rated factor, according to the respondents. It is extremely important to understand the need for a project, i.e., why it is needed and what will be the end results if the project has opted. Without any vital need, a project is not considered. Once the need is justified to a reasonable extent, then its outcomes and returns are analyzed that whether it will be helpful in fulfilling the desired needs. If it fulfills then a project is brought into consideration else it will not. This is the main cause of any feasibility study for a project [10].

\section{E. Financial Turnover Mechanism}

For any business sector, the most crucial part is the turnover of capital. Investment of capital in any project is always exposed to risk. The success and failure of a project govern the capital recovery. Hence it is foremost to develop an effective financial turnover mechanism to clearly examine the type of projects in which capital is invested, the period in which recovery is possible and the factor of obtaining maximum returns.

\section{F. Quality Management System}

Moderately rated by the respondents, quality management system is the reflection of any project. It warrants the success or failure of any project at any stage. Development of QMS is necessary for evaluation of cost and its benefits.

Before consideration of any project, its quality management is always taken into account so as to gather many timely returns from a project. 


\section{G. Procurement Cycle}

Procurement plays a very crucial role in overall project life. It remains associated with the project from the day of its inception till its completion. Its effectiveness is one of the key factors in any project success. Hence it is important to develop an efficient procurement cycle in order to arrange all sorts of resources (Machinery, Manpower, Material and Money) timely. The rating by the respondents shows the level of its significance.

\section{H. Contractual Agreement}

A contractual agreement is another influential factor that always plays a major part in any project consideration. Scope, duration and finance of a project decide the type of contractual agreement to be incorporated to make a project's success. Various types of contractual agreements are considered always before project inception, along with their effectiveness and validity according to the domain of project type. Moderate responses were gathered for this factor too, from our respondents.

\section{CONCLUSION}

This study was aimed to facilitate the construction industry by recognizing the most important factors that affect the need for feasibility analysis for local construction projects. The factors throughout the construction project life cycle were identified and perception of various stakeholders, i.e. client, consultants and contractors were taken on them. This research has explored some critical factors that are responsible for conducting a feasibility study and then ranked them from the viewpoints of three different respondent groups (i.e., client, consultant and contractor). Spearman's rank correlation tests indicate that the highest (64\%) degree of agreement appeared between contractors and consultants, 27\% appeared between clients and contractors, while $15 \%$ of agreement appeared between consultants and clients in respect of ranking these factors. It was revealed that there is a moderate and positive correlation found between the stakeholder's, perceptions, of these factors which depict that the stakeholders are somehow agreed with each other. The research findings could help the construction professionals to obtain much better reasons for carrying out feasibility analysis of local projects. However, our study is limited to identifying the factors only which will help the researchers find out the way to ensure feasibility analysis for local projects, and that findings are not only useful for participants in the Pakistani construction industry, but also in other developing countries too.

\section{REFERENCES}

[1] Momin Mukherjee and Sahadev Roy, "Feasibility Studies and Important Aspect of Project Management" International Journal of Advanced Engineering and Management vol. 2, No. 4, pp. 98-100, 2017.

[2] Khalied Hyari and Amr Kandil, "Validity of Feasibility Studies for Infrastructure Construction Projects" Jordan Journal of Civil Engineering, Vol 3, No. 1, pp. 66-77, 2009.

[3] Azza Abou-Zeid, Ashraf Bushraa and Maged Ezzat, "Overview of Feasibility Study Procedures for Public Construction Projects in Arab Countries" JKAU: Eng. Sci., vol. 18 No. 1, pp: 19 - 34, 2007.
[4] C. S. J. J. P. a. A. H. J. Rawshan Ara Begum, "A benefit-cost analysis on the economic feasibility of construction waste minimization," The Case of Malaysia, Resources, Conservation and Recycling, pp. 86-98, 2006.

[5] D. M. S. L. a. L. C. Goode, "Back to Basics: the Feasibility Study," CIM Bulletin, 84, No 953, 1991.

[6] A. K. Khaleid Hyari, "Validity of Feasibility Studies for Infrastructure Construction Projects," Jordan Journal of civil Engineering, vol. 3, no. 1, 2009.

[7] T. L. M. D. Y. -C. E. D. Jason B. Forsyth, "Feasibility Study of a Wearable Carbon Monoxide," Virginia Polytechnic Institute and State University Blacksburg, VA 24061, pp. 28-35, 2011.

[8] W. R. L. V. S. Rotterc, "Evaluation of the economic feasibility for the recycling of construction and demolition waste in China-The case of Chongqing," Resources, Conservation and Recycling, vol. 54, no. 6, pp. 377-389, 2010.

[9] M. F. Bonsang Koo, "Feasibility Study of 4D CAD in Commercial Construction," Journal of Construction Engineering and Management, vol. 126, no. 4, 2011.

[10] R. N. M. Shabtai Isaac, "Feasibility Study of an Automated Tool for Identifying the Implications of Changes in Construction Projects," Journal of Construction Engineering and Management1, vol. 134 , no. 2,2008 